\title{
LEFT VENTRICULAR LEAD PLACEMENT FOR PACING AND SENSING IN A PATIENT WITH ARRHYTHMOGENIC RIGHT VENTRICULAR CARDIOMYOPATHY UNDERGOING ICD IMPLANTATION
}

\author{
Jane Taleski ${ }^{1,2}$, Šime Manola², Vjekoslav Radeljić ${ }^{2}$, Nikola Bulj², \\ Diana Delić Brkljačić ${ }^{2}$ and Nikola Pavlović ${ }^{2}$
}

\author{
${ }^{1}$ Department of Cardiology, Division of Cardiac Electrophysiology and Electrostimulation, \\ Skopje, Republic of Macedonia; \\ ${ }^{2}$ Department of Cardiology, Sestre milosrdnice University Hospital Centre, Zagreb, Croatia
}

\begin{abstract}
SUMMARY - We present a case of a 64-year-old female patient scheduled for implantable cardioverter defibrillator (ICD) implantation due to arrhythmogenic right ventricular cardiomyopathy (ARVC). Dual coil, active fixation ICD lead was introduced through the axillary vein. More than 20 positions were changed in the right ventricle (RV) (outflow tract, high, mid and apical septum, inferobasal, apical and lateral wall). Maximum $\mathrm{R}$ wave amplitude was $2 \mathrm{mV}$ with pacing threshold of $0.5 \mathrm{~V}$. Since the sensing was inappropriate, we decided to place the pace/sense lead of the ICD in the coronary sinus. The lead was placed in the basal part of the lateral vein. The pacing threshold was 1.0 $\mathrm{V} / 0.40 \mathrm{~ms}$ and $\mathrm{R}$ wave was $9 \mathrm{mV}$. The lead was connected to the ICD sense-pace port and high voltage coils were connected in the usual way. The RV sense-pace lead was capped off. The device sensed an $\mathrm{R}$ wave of $7.0 \mathrm{mV} 48$ hours later. The purpose of this report is to show a possible solution of sensing problems during an ICD implantation in a patient with ARVC.
\end{abstract}

Key words: Arrhythmogenic right ventricular dysplasia; Defibrillators, implantable; Death, sudden, cardiac; Case reports

\section{Introduction}

Lead placement and obtaining adequate sensing parameters in arrhythmogenic right ventricular cardiomyopathy (ARVC) patients during implantable cardioverter defibrillator (ICD) implantation can be troublesome and difficult due to extensive fibro-fatty replacement of the right ventricular myocardium. In selected cases, the pace-sense lead can be placed in the left ventricle (LV) through the coronary sinus during the same procedure avoiding repeated procedures such

Correspondence to: Jane Taleski, MD, Department of Cardiology, Division of Cardiac Electrophysiology and Electrostimulation, Mother Teresa 17, 1000 Skopje, Republic of Macedonia E-mail: jtaleski@gmail.com

Received October 16, 2018, accepted February 21, 2019 as subcutaneous ICD or epicardial lead placement. The purpose of this report is to show a possible solution when sensing problems are encountered during an ICD implantation in a patient with ARVC. In such a patient, due to inadequate sensing parameters in the right ventricle, we decided to place the pace/sense lead in the coronary sinus.

\section{Case Report}

A 64-year-old female patient with ARVC was referred to our center for ICD implantation. She presented with occasional episodes of dyspnea, weakness, syncope and non-sustained ventricular tachycardia (NSVT) on Holter electrocardiogram (ECG). She also had an episode of sustained monomorphic VT which 


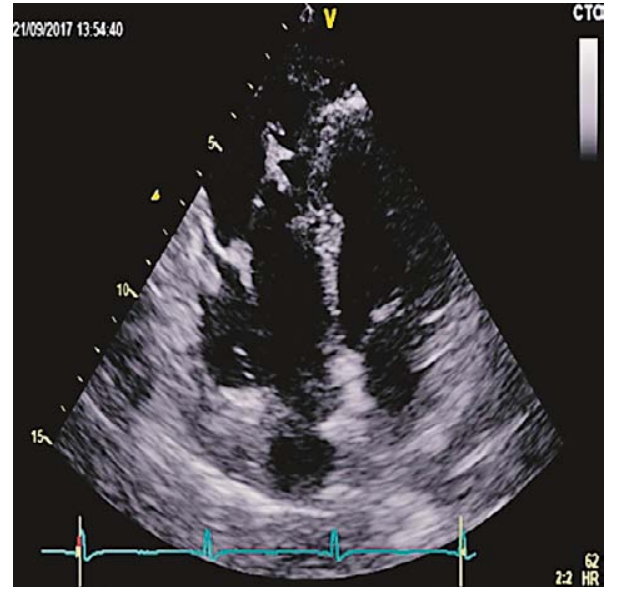

Fig. 1. Echocardiographic image: enlargement of the right ventricle; hypokinetic and dyskinetic apical and lateral wall shown over the echocardiographic parasternal long axis (PLAX) view.

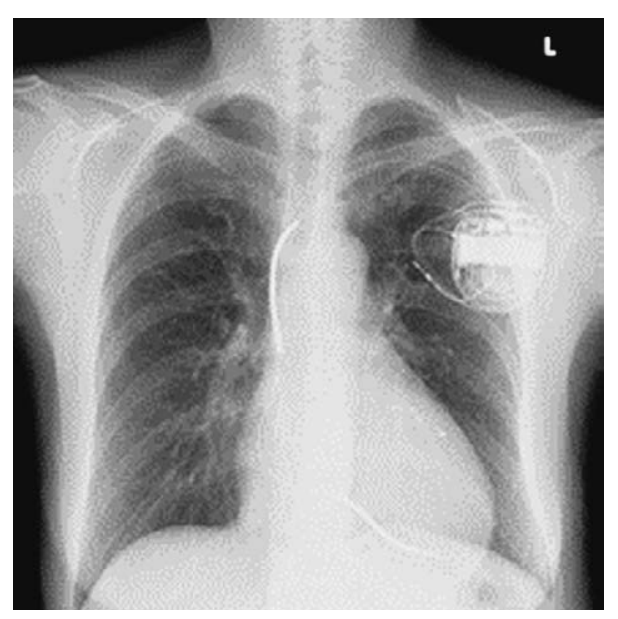

Fig. 2. Chest $x$-ray after implantable cardioverter defibrillator (ICD) system implantation (anterior/posterior projection, AP) with left ventricle (LV) lead visible.

was successfully cardioverted to sinus rhythm. She had a family history of sudden cardiac death. ECG showed sinus rhythm with right bundle branch block, inverted T waves in the precordial leads and visible epsilon wave. Echocardiography showed enlargement of the right ventricle (RVOT $40 \mathrm{~mm}$ ), hypokinetic and dyskinetic apical and lateral wall, and reduction of the systolic longitudinal function of the right ventricle (RV) (Fig. 1). Coronary angiography was normal.

With four major and two minor criteria fulfilled, ARVD was diagnosed ${ }^{1}$. She was scheduled for ICD implantation for secondary sudden cardiac death prevention. We introduced a dual coil, active fixation ICD lead through the axillary vein (Medtronic Sprint Quattro Secure, 6947-65, DF-1/IS-1, Minneapolis, USA). More than 20 positions were changed in the RV (high, mid and apical septum, infero-basal, apical and lateral wall) and even right ventricular outflow tract (anterior and septal). However, maximum $\mathrm{R}$ wave amplitude was $2 \mathrm{mV}$ with pacing threshold of $0.5 \mathrm{~V}$ with pulse weight $0.40 \mathrm{~ms}$.

Due to inappropriate sensing in several RV segments, at the time of the procedure we decided to place the LV epicardial lead through the coronary sinus as pace/sense lead of the ICD system. The LV lead (Biotronik Sentus ProMRI L85, IS-1, Berlin, Germany) was placed in the basal part of the lateral vein (Fig. 2). The pacing threshold was $1.0 \mathrm{~V} / 0.40 \mathrm{~ms}$ and $\mathrm{R}$ wave was $9 \mathrm{mV}$. ICD lead was placed in the RV apex. LV lead was then connected to the ICD sense-pace port and the high voltage coils of the RV lead were connected in the usual way. The RV sense-pace lead was capped off. The device sensed an $\mathrm{R}$ wave of $7.0 \mathrm{mV}$ after the procedure and 48 hours later.

\section{Discussion}

Arrhythmogenic right ventricular cardiomyopathy is a hereditary disease characterized by fibro-fatty replacement of myocardium, occurrence of ventricular arrhythmias and risk of sudden cardiac death ${ }^{2}$ ICD implantation is indicated in selected patients ${ }^{3,4}$. Achieving stable lead position with adequate sensing can be challenging. We present a case of effective solution of the ICD lead sensing problem during the implant procedure by placing the $\mathrm{LV}$ epicardial lead as ICD pace-sense lead. Decision to use DF-1/IS-1 connector ICD and compatible lead was made based on the previously described possible difficulties to ensure adequate sensing or pacing parameters in the $R V$ in patients with ARVD. We were aware of possible limitations in this type of connector, but it gives us freedom to use another pace/sense lead in cases like this. Although there are other options such as placing the epicardial ICD system or possibly subcutaneous ICD, this would usually have to involve another invasive procedure. With our approach, there are concerns regarding the LV lead dislodgement, however, it has 
been previously described ${ }^{5,6}$. In the previous cases described by Niazi et al. ${ }^{5}$ and Lochy et al. ${ }^{6}$, this approach was anticipated based on the voltage maps or previous pace/sense problems and the LV lead placement was planned before.

We can conclude that the difficulties in ICD lead positioning in ARVC patients can be safely overcome by placing the epicardial pace/sense LV lead.

\section{References}

1. Marcus FI, McKenna WJ, Sherrill D, Basso C, Bauce B, Bluemke DA, et al. Diagnosis of arrhythmogenic right ventricular cardiomyopathy/dysplasia: proposed modification of the task force criteria. Circulation. 2010 Apr 6;121(13): 1533-41. doi: 10.1093/eurheartj/ehq025

2. Azaouagh A, Churzidse S, Konorza T, Erbel R. Arrhythmogenic right ventricular cardiomyopathy/dysplasia: a review and update. Clin Res Cardiol. 2011 May;100(5):383-94. doi: $10.1007 / \mathrm{s} 00392-011-0295-2$
3. Priori SG, Blomström-Lundqvist C, Mazzanti A, Blom N, Borggrefe M, Camm J, et al. 2015 ESC Guidelines for the management of patients with ventricular arrhythmias and the prevention of sudden cardiac death: The Task Force for the Management of Patients with Ventricular Arrhythmias and the Prevention of Sudden Cardiac Death of the European Society of Cardiology (ESC). Endorsed by: Association for European Paediatric and Congenital Cardiology (AEPC). Eur Heart J. 2015 Nov 1;36(41):2793-867. doi: 10.1093/eurheartj/ehv316

4. Pavlović N, Manola Š, Vražić H, Vučić M, Brusich S, Radeljić $\mathrm{V}$, et al. Recommendations for perioperative management of patients with cardiac implantable electronic devices. Acta Clin Croat. 2018 Jun;57(2):383-90. doi.org/10.20471/acc.2018.57.02.22

5. Niazi I, Rennick N, Kiemen JA, Sra J. Left ventricular pacing in right ventricular cardiomyopathy: blessing or blunder? Pacing Clin Electrophysiol. 2013 Mar;36(3):e64-6. doi: 10.1111/ j.1540-8159.2011.03201

6. Lochy S, François B, Hollanders G, Provenier F. Left ventricular sensing and pacing for sensing difficulties in internal cardioverter defibrillator therapy for arrhythmogenic right ventricular cardiomyopathy. Europace. 2010 Aug;12(8):1195-6. doi: 10.1093/europace/euq091

Sažetak

\title{
POSTAVLJANJE ELEKTRODE U LIJEVU KLIJETKU ZA STIMULACIJU TIJEKOM UGRADNJE KARDIOVERTER DEFIBRILATORA KOD BOLESNICE S ARITMOGENOM DISPLAZIJOM DESNE KLIJETKE
}

\author{
J. Taleski, Š. Manola, V. Radeljić, N. Bulj, D. Delić Brkljačić i N. Pavlović
}

Prikazujemo slučaj bolesnice s aritmogenom displazijom desne klijetke (ARVC) previđene za ugradnju kardioverter defibrilatora (ICD). Defibrilatorska elektroda s aktivnom fiksacijom postavljena je desnim aksilarnim pristupom. Adekvatni parametri stimulacije nisu se mogli postići na više od 20 pozicija u desnoj klijetki (izlazni trakt, bazalni, srednji i apikalni septum, inferobazalno, apikalno i na slobodnom zidu). Maksimalna amplitura $\mathrm{R}$ vala bila je $2 \mathrm{mV}$ i prag stimulacije 0,5V. S obzirom na to da parametri nisu bili adekvatni odlučili smo se za postavljanje dodatne elektrode u bazalni segment lateralne grane koronarnog sinusa za sensing i stimulaciju. Amplituda $\mathrm{R}$ vala bila je $9 \mathrm{mV}$, a prag stimulacije $1 \mathrm{~V}$. Cilj ovog prikaza slučaja je opisati potencijalna rješenja problema sa sensingom i stimulacijom tijekom ugradnje ICD-a kod bolesnika $s$ aritmogenom displazijom desne klijetke.

Ključne riječi: Aritmogena displazija desne srčane klijetke; Defibrilatori, ugradbeni; Smrt, iznenadna, srčana; Prikazi slučaja 